\title{
FFT 法による木質繊維板の配向評価
}

\author{
村 田功二* 藤 田 稔** \\ FFT-Estimation of Fiber Orientation on Wood Fiberboard
}

by

\author{
Koji Murata* and Minoru Fujita**
}

\begin{abstract}
The property of many engineering woods depends on the shape and orientation of their elements. This paper describes an attempt to estimate the 3-dimensional fiber orientation in insulation fiberboard (IB).

Serial sections of IB were sliced off at every $50 \mu \mathrm{m}$ parallel to the board plane by a sliding microtome. Before sectioning, the specimen was embedded in epoxy resin and cured. Then, it was boiled in water for several hours to make the resin moderately soften. The orientation values were calculated on 2-dimensional Fourier transform image analysis. Analytical value indicates that fibers near the both surfaces orient to machine direction and the orientations decrease on inner plane. Section thickness was shown to affect the orientation values. The value was underestimated on a too thin section, because fibers are fragmented. On the other hand, obscure image of overlapping fibers on a too thick section gave also underestimated value. Some ideas are proposed to search for appropriate thickness.
\end{abstract}

Key words : Wood fiberboard, Orientation analysis, Fourier transform, Fiber orientation

\section{1 緒言}

木材資源を有効に活用するために，低質な材料から作 られる PB（particleboard）や木質繊維板が注目され，そ の需要が年々増加している．特に OSB (oriented strand board）に代表されるような構成要素に配向性を持たせ て機能性を高めた材料が関心を集めている。より高い機 能性を追求するためにはボード全体としての配向性にと どまらず，表面や内部の各々に効率的な配向性の付与が 試みられるだろう。そして一方ではこれら配向性の的確 な評価法の確立が重要になると考えられる。最近では MDF (medium density fiberboard) などでも機能性を高 めるために，配向性を持たせたものが報告されており ${ }^{1)}$, 今後もいろいろな機能性を付与された木質䋊維板が開発 されると思われる。木質系ボード以外でも，紙，不織布， FRP (fiber-reinforced plastics) 等で，その構成要素の 配向性と物性の関係が注目され，その配向性の計測が試 みられてきた。特に, 近年のコンピュータの普及と性能 の向上により，画像解析法が身近なものとなり，それを 用いた多数の報告がなされている。紙では, FFT（fast Fourier transform）処理を用いて薄い紙の配向性を評価 した Yuhara $ら^{2)}$, 比較的厚い紙について，粘着テープ によって紙の表裏両面から繊維の層を逐次はぎ取り, 非 常に薄い紙層の顕微鏡画像を作製し, 試験線交点計測法 (intersection counting method) で評価した板東ら ${ }^{3)}$ が ある. $\mathrm{Xu}^{4)}$ は, 細線化技術を用いて不織布の配向性を評 価した. Yaguchi ら ${ }^{5)}$ は, 試験線交点計測法と Prewitt
オペレータを用いた画像濃淡法 (image intensity method) の 2 つの方法を用いて, 薄い FRPの軟 X 線写真から繊 維配向性を評価し, またPourdeyhimi ${ }^{6)}$ は, FRPの繊 維配向の測定を目的として, シミュレーション画像の繊 維の配向状態を, 濃淡画像の FFT と, 直接追跡法 (direct tracing method) の 2 つで測定し，比較を行っ た. 両者とも, 複雑に交錯し, 識別の難しい繊維の配向 を測定するには，濃淡画像からの計算方法が良いとして いる.

これまでの報告は比較的薄い試験体を使用したものが 多く, 画像作製が困難な木質ボード等の厚い供試材につ いての解析例は少ないが, 藤田ら ${ }^{7)}$ はPB の表面模様を 複写機で画像化し，また製造過程で落下するパーティク ルを受け板に逐次取り出して写真撮影し, これらをFFT 処理した. 特に FFT 処理前後の画像処理を改良し, 2 次 元パワースペクトルパターン (PSP (power spectral pattern)）の極座標解析を行うことで配向性を的確に評価し た。しかしながら, これはPBの表面に見られる配向性 を評価したに過ぎず，配向性と機能性の関係を十分に考 察するためには，さらに内部の配向状態を調べることが 必要である。

MDF や IB (insulation fiberboard) では解離された 数 $10 \mu \mathrm{m}$ 幅の短繊維あるいはこれらが数本集まった繊維 束が基本的な形態要素である。これらが接着剤を添加さ れて湿式あるいは乾式でかく拌積層されて数 $\mathrm{mm}$ 以上の 厚さのボードに成型される，原材料や抄造工程は製紙の

$\dagger$ 原稿受理 平成 10 年 2 月 17 日 Received Feb. 17, 1998

* 正 会 員 京都大学大学院農学研究科森林科学専攻 テ606-8502 京都市左京区北白川追分町, Div. of Forest and Biomaterials Science, Grad. School of Kyoto Univ., Sakyo-ku, Kyoto, 606-8502

** 京都大学大学院農学研究科森林科学専攻 $=606-8502$ 京都市左京区北白川追分町, Div. of Forest and Biomaterials Science, Grad. School of Kyoto Univ., Sakyo-ku, Kyoto, 606-8502 
場合と類似している点も多いが, 繊維相互の接着や 3 次 元的絡み合いが紙の場合と異なる。ボードの厚さそのま までは，表層を除き繊維要素を画像化することは不可能 であり，紙のように粘着テープで内部の䋊維層をはぎ取 ることも困難である。そこでこれら纎維板の内部構造の 観察にはボード面に平行あるいは垂直に切り出された切 片で繊維構造を画像化することが必須となる。しかしな がら繊維板の薄切は非常に困難な作業である。

従来木材などの光学顕微鏡観察にはスライディングミ クロトームを用いて, 数 $10 \mu \mathrm{m}$ 厚さで $1 \mathrm{~cm} \times 1 \mathrm{~cm}$ 程度 の広さを持つ断面切片が作製されてきた。またより精密 な電子顕微鏡観察には試料の空隙をエポキシ樹脂などで 充填固化させ，ダイヤモンドナイフ等を装着した超ミク ロトームで薄切する超薄切法が採用されてきた。この方 法では非常に精度の高い薄切片を作製することができる が，薄片の厚さは数 $\mu \mathrm{m}$ 以下に限られ，また薄片の面積 も数 $\mathrm{mm} \times$ 数 $\mathrm{mm}$ 程度の狭いものとなる.この限られ た面積では木質繊維板の基本構成要素（例えば針葉樹仮 道管では数 $10 \mu \mathrm{m}$ の太さと数 $\mathrm{mm}$ の長さ）を多数含むこ とが不可能となる。枀こで樹脂包埋法を改良し，十分な 厚さと面積を持つ切片作製法を考案し，抄造方向に繊維 配向の見られる低比重 IB について，表面から内部へと ボード面に平行な切片を連続的に作製して，ボードの厚 さ方向に打ける繊維配向性の変化の測定を試みた。

\section{2 解析方法の検討}

\section{$2 \cdot 1$ フーリエ変換法による解析の手順}

濃淡画像から繊維配向を評価する方法として, 濃淡画 像を 2 次元 FFT 処理して得られる PSP 解析する方法 を採用した。濃淡画像を用いるため画像のコントラスト が解析に大きく影響するので，全画素の最大濃度と最小 濃度がそれぞれ 255 と 0 になるように線形変換し，コン トラストを強調した。また，画像処理装置に取り込まれ た画像は，矩形ではあるがこれをそのまま 2 次元 FFT 処 理すると画像端の直線部分の影響が出て, パワースペク トルの垂直方向と水平方向に鋭いピークが現れる。これ は，離散的フーリエ変換では，取り込んだ有限のデータ を無限に繰り返すと仮定して計算しているために，不連 続部分の影響が現れるからである。この影響を少なくす るため，画像を円形 (半径 240 画素) に切り取り，周辺 部の画素の濃度を標本画像のほぼ中央值（128）にそ弓 えた.

濃淡画像の 2 次元 FFT 処理には, 画像処理装置付属 (LUZEX-FS，ニレコ社製）の機能を使用し，出力された PSP の解析にはパーソナルコンピュータを使用した。解 析方法としては, 前川 ${ }^{8)}$ が報告している PSP の極座標解 析を応用した．PSPの全方位を 32 個の扇型に分割し， 直交座標で表されているPSPのそれぞれの画素をその扇 形に当てはめることで極座標変換を行った．この極座標 解析で注意すべきことは探査する周波数領域の選択であ
る. 細長い矩形もしくは長楕円形の形態要素の 2 次元 フーリエ変換したPSP では元の形態要素の長軸に垂直な 方向に細長く現れる。すなわち元の形態要素の長軸方向 に起因するパワーは低周波領域に限られ，角度分布は短 軸方向の寸法の逆数となって分散する傾向がある。一方 短軸（幅）方向のそれは高周波領域にまでおよび，角度

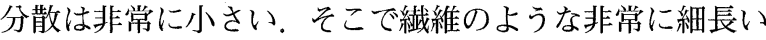
形態要素の方位を検出するには高周波領域の計測が適し ている。またコンピュータ画像処理の実際的な面に打い ても，低周波での計測には問題が多い，画像处理装置で は一定寸法の画素が方眼状の直交座標に配置されている. これに対してPSP は極座標上に展開されるが，低周波領 域（原点に近い領域）では高周波領域（原点から遠い領 域）に対して画素が相対的に粗くなり誤差を招きやすい. 一方，高周波領域ではパワーレベルが低下する弱点もあ るので，これらの長短所を勘定して中一高周波領域を ドーナツ状に探査し，パワー分布を方位ごとに集計した。 実際に集計した中一高周波成分は，半径が 100 画素（元 の画像 5 画素の周期に相当する）功 255 画素（元の画 像 2 画素の周期に相当する）までである.

\section{$2 \cdot 2$ シミュレーション画像の繊維配向の評価}

先述の研究者たちにより，画像を 2 次元 FFT 処理する ことで構成要素の配向性を評価することが可能であるこ とが明らかにされてきた。しかし，厳密な定量性には未 だ検討すべき点もある．今回の解析方法においても，実 際の配向状態と解析結果の差にみられる特性を明確にし ておく必要がある。そこで，繊維の配向状態が既知のシ ミュレーション画像を用いて, 解析方法の検討を行った. シミュレーション画像では，疑似繊維は長さが 100 画素, 幅が 3 画素, 濃度階調が 255 とし，背景の濃度階調は 1 とした。つまり，疑似繊維から背景への移行部（エッジ） は濃度階調が 255 から 1 亿と急激に変わる不連続なもの とした．また，半径 256 画素の円より外側の画素は濃度 階調を 128 と設定し，その円の中に全部で 321 本の疑似 纎維を配置, 座標は乱数を用いてランダムなものとした (Table I).

これらのシミュレーション画像とそれらを 2 次元 FFT 処理することにより得られたPSP を Fig. 1に示す。 ミュレーション画像で設定した 16 方位にパワースペクト ルのピークがシャープに現れているのが分かる。さらに これらの PSPを極座標解析した結果を Fig. 2 に示す. そこでは配向方向の值が小さく見積もられ，それに直交 する方向では大きめに見積もられている傾向がみられる。 特に 45 度に瀻維配向させたものではその傾向が著しい． 方眼状の離散情報を計算していることが原因のひとつと も考えられるが，詳しくは今後の研究課題となろう。し かし，多少のばらつきや増減はあるものの繊維配向の特 性をほほ正確に評価しており，インシュレーションボー ドの繊維配向の解析に使用できると思われる。 


\section{IB の纎維配向の測定}

\section{3・1 試験体の作製}

低比重（SG：0.23）のIB（厚さ10mm）秥ら，20mm (抄造方向) $\times 10 \mathrm{~mm}$ (ボード幅方向 $) \times 10 \mathrm{~mm}$ (厚さ) の試験体を作製した。これらを電子顕微鏡試料作製法で

Table I. Fiber distribution on simulation images.

\begin{tabular}{|c|c|c|c|}
\hline $\begin{array}{c}\text { Orientation direction } \\
\text { [degree] }\end{array}$ & at $90^{\circ}$ & at $45^{\circ}$ & at random \\
\hline 0.00 & 2 & 19 & 20 \\
\hline 11.25 & 4 & 26 & 20 \\
\hline 22.50 & 8 & 33 & 20 \\
\hline 33.75 & 13 & 37 & 20 \\
\hline 45.00 & 19 & 39 & 20 \\
\hline 56.25 & 26 & 37 & 20 \\
\hline 67.50 & 33 & 33 & 20 \\
\hline 78.75 & 37 & 26 & 20 \\
\hline 90.00 & 39 & 19 & 20 \\
\hline 101.25 & 37 & 13 & 20 \\
\hline 112.50 & 33 & 8 & 20 \\
\hline 123.75 & 26 & 4 & 20 \\
\hline 135.00 & 19 & 2 & 20 \\
\hline 146.25 & 13 & 4 & 20 \\
\hline 157.50 & 8 & 8 & 20 \\
\hline 168.75 & 4 & 13 & 20 \\
\hline Total & 321 & 321 & 320 \\
\hline & & & \\
\hline
\end{tabular}

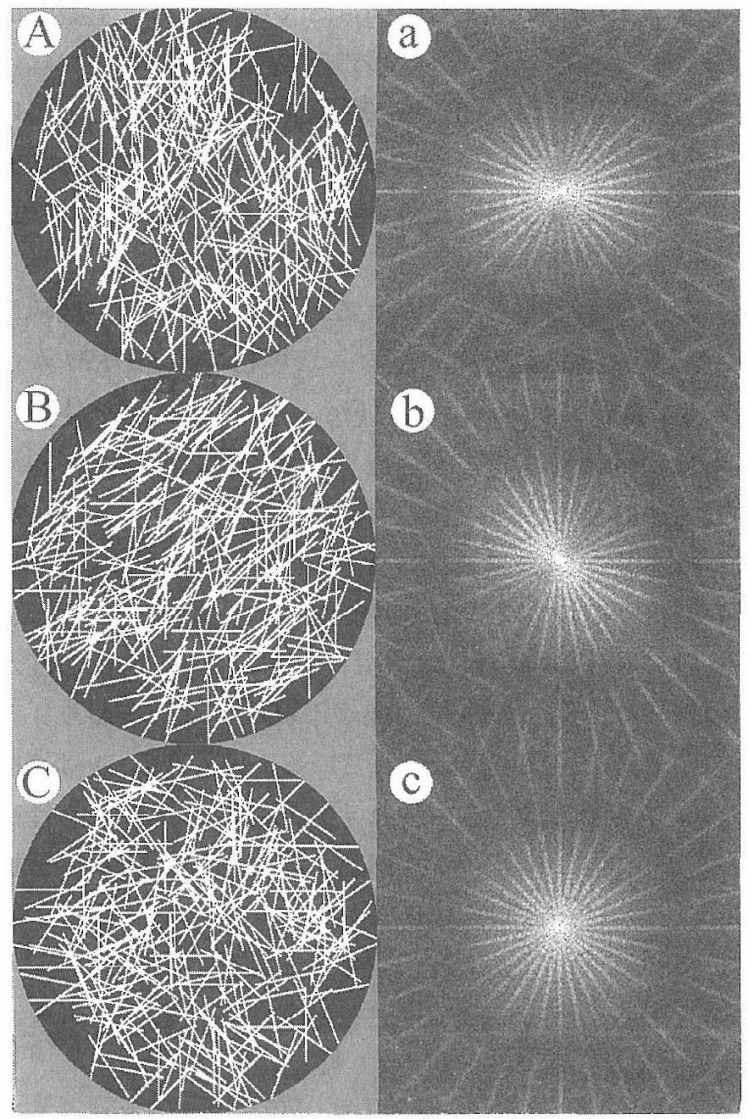

Fig. 1. Simulation images (left) and power spectral patterns (right). Weak power was enhanced with logarithmic function, A, a : Oriented at $90^{\circ}, \mathrm{B}$, b : at $45^{\circ}, \mathrm{C}, \mathrm{c}:$ at random.
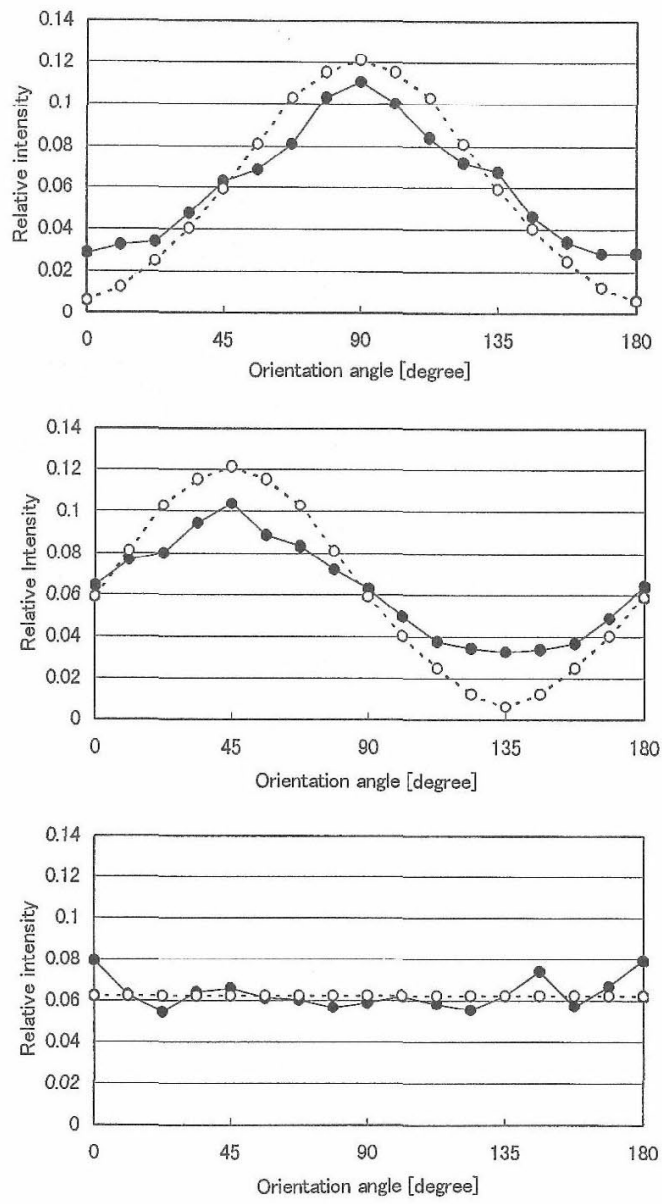

Fig. 2. Orientation distribution functions for simulation images, Top : oriented at $90^{\circ}$, Middle: at $45^{\circ}$, Bottom : at random, $\bigcirc$ : Original distribution of simulated fibers, 0 : Power distribution after FFT-treatment.

調合したエポキシ樹脂液（ルベアック 812（ナカライテ スク社）62 容量部，ルベアック DDSA（同）100 容量部，

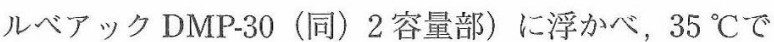
半日扮いてボードの低面から樹脂液をボードの空隙に浸 透させた。そして $60{ }^{\circ} \mathrm{C} て ゙ 2$ 日間静置して樹脂を硬化さ せた。樹脂は吸湿によりもろくなるので通常は乾燥させ て保仔するが，本報では厚い切片を得るために敢えて吸 水軟化させた。すなわち試験体の周りの樹脂を鋸て除去 してから熱水で数時間煮沸して纎維成分および樹脂部分 に十分に吸水させて軟化した。そしてスライディングミ クロトームに装着して，切削面が試験体の上面拉よび下 面（ワイヤー側）に平行になるように注意深く角度調節 をし，乥れ艺れの面からスチールナイフで $50 \mu \mathrm{m}$ 每に 10 枚の切片を切り出した。切片面積を非常に大きくしたの で, 切削時にナイフの試験片への潜り达みが生じて, 少 し厚い切片と薄い切片が忞互に切り出される傾向があっ た。また，一枚の切片中に扔いても多少の厚さむらもあ った。一方，抄造方向と平行にボード面に垂直な $50 \mu \mathrm{m}$ 厚さも作成した。これら切片はカナダバルサムで封入し 光学顕微鏡用標本とした。 


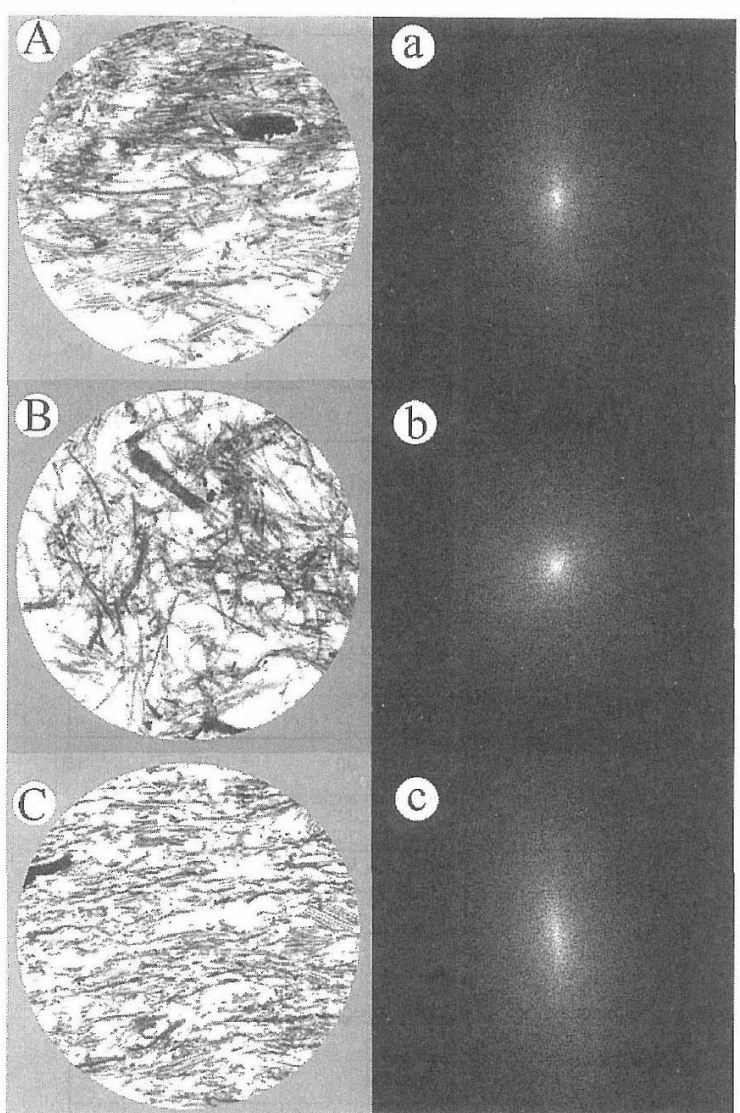

Fig. 3. Sample images of IB (Left) and their power spectral patterns (Right), A, a : Upper side of IB, $\mathrm{B}, \mathrm{b}$ : Lower side, $\mathrm{C}, \mathrm{c}$ : cross section vertical to the board plane.

\section{$3 \cdot 2$ 画像の入力}

切り出した試料を，顕微鏡（SZH10，オリンパス社製） と CCD カメラ (XC-003，ソニー社製）を用いて画像処 理装置（LUZEX-FS）に, 256 濃度階調の濃淡画像とし て入力し, 輝度の最大值が 255 , 最小值が 0 となるよう にコントラストを調節した。ここでは，抄造方向を水平 に入力した。

画像处理装置の解像度は $512 \times 512$ 画素で亦るが, CCD カメラの性能のため, 取り込まれた画像は 480 画素 (垂直方向） $\times 512$ 画素（水平方向）で苟った。1 画素は 約 $6.3 \times 6.3 \mu \mathrm{m}$ に相当し，取り込まれた範囲は約 $3.0 \times$ $3.2 \mathrm{~mm}$ であった。 また，一枚の切片につき 6 視野の画像 を入力した。

\section{$3 \cdot 3$ 測定結果}

入力した画像を処理したものと公れを2 次元 FFT 处理 して得たPSPの一例を Fig. 3 に示す. 上層から切り出 したサンプルでは抄造方向（水平方向）に配向している のがはっきりとわかり（Fig. 3-A），PSPでもパワースペ クトルが垂直方向に強く現れて，配向状態を反映してい ることが確認できる (Fig. 3-a)。下層から切り出したサ ンプルでは，上層部からのものに比べ配向はかなり緩や かである（Fig. 3-B， b）。一方ボード面に垂直な切片で
は，纎維の多くはだ円状に切断されているが (Fig. 3-C), 穴のパワースペクトルパターン法明睹な配向性を示す (Fig. 3-c)。これは䋊維のほとんどがボード面にほぼ平行 に配向しているからである。次に上面と下面から，并れ ぞれ表層から $0 \mu \mathrm{m}, 250 \mu \mathrm{m}, 500 \mu \mathrm{m}$ 離れたの 3 力所の試 料を解析して得た配向分布関数を Fig. 4 に示す。層部 に抢いては，表層近くで水平方向にはっきりとした繊維

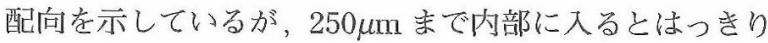
としたピータはみられず，緩やかに水平方向に配向して いる状態になる。穴の状態は $500 \mu \mathrm{m}$ 内部でも人きな差は ない，下層部では 3 地点のいずれにも大きな差は見られ ないが，やはり緩やかに水平方向に配向している傾向は 見られ，内部に入るほど配向性涂々に小さくなって いる。

抄造方向への䋊維配向の程度を数量化するするために, 抄造方向配向度 ORM (orientation rate on machine direction）を以下のように定義した。

$$
O R M=\frac{\text { 抄造方向 }\left(0 \pm 45^{\circ}\right) \text { の成分 }}{\text { 全方向 }\left(0 \pm 90^{\circ}\right) \text { の成分 }}
$$

1 枚の切片から得た 6 視野の測定結果を平均した ORM の，ボード厚さ方向に和沙る変化を Fig. 5 に示す。層 では，表面近くでかなりはっきりと抄造方向に繊維配向 しているが，内部に入るに従い繊維配向が緩やかになっ ているのがわかる，上層表面活どではないが，下層表面 でも緩やかな水平方向への繊維配向を示して抢り，この 場合も内部に進むに従って繊維配向が緩やかになってい るのがわかる。さらに ORMの変化を詳しく見ると，值 に多少のばらつきが見られ，特に下層部に抢いては交互 に增減を繰り返している。これらの結果さ測定した光学 顕微鏡用標本と照らし合わせると，ナイフの潜り込みに よって薄片厚さが不均一となった場合には，ORMが小 さくなる傾向か認められた（Fig，6）。これは試験体中に 本来長い絨維要素があっても，薄切の際にこれらが斜め に切断されるために配向性が過小評価されたと判断され る (Fig. 6-A)。極端に切片が薄い場合にはほとんどす心゙ ての繊維が断片化されて切片面ではだ円形となってしま う。Fig. 6-B の場合には，切片が特に厚くて繊維密度が 過重になり，個々の繊維の像が不鮮明になって打り，只 の結果 $O R M$ も過小評価られている。Fig. 6-C, D は適度 な切片厚さで市ると考えられ，計測估が的確な配向性を 示吉と判断さ机る。今回は実際に測定された面積 $(3.0 \mathrm{~mm} \times 3.2 \mathrm{~mm})$ に詨して $10 \mathrm{~mm} \times 20 \mathrm{~mm}$ もの広い切 片を作製したので，切片に厚さむらが生じたが，切片の 面積を小さくすることで厚さむらを小さくなると考光ら れる。

いずれにしても配向性の評価が切片厚さに影響される ことが明らかとなったので，今後は試験体の特徴を考虑 して切片厚さを選択する必要で要る。关の適切な厚さを 評価する方法として，PSPの周波数解析が考光られる。 

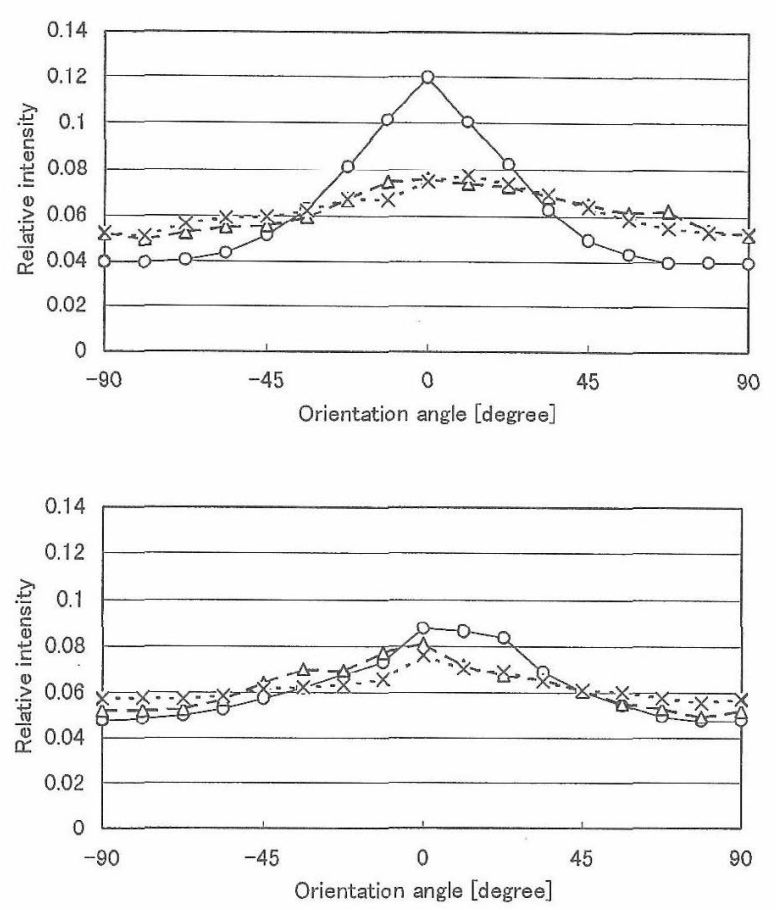

Fig. 4. Orientation distribution function of IB, Top: Upper surface, Bottom : Lower surface, $O$ : the distance from the surface is $0 \mu \mathrm{m}, \triangle: 250 \mu \mathrm{m}$, $x: 500 \mu \mathrm{m}$.

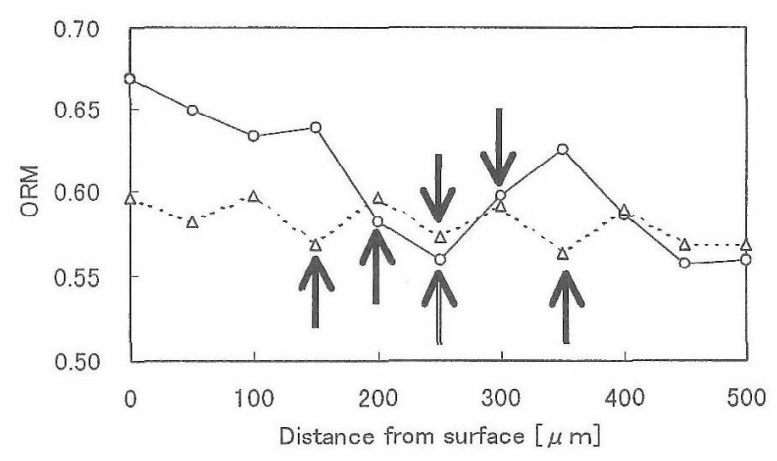

Fig. 5. Changes of orientation rate on machine direction $(O R M)$ near the surface of $I B, O$ : Upper surface, $\triangle$ : Lower surface, $\rightarrow$ : values on too thin sections, $\Rightarrow$ : values on a too thick section.

Table II . Orientation values (ORM) and image characters corresponding to Fig. 6.

\begin{tabular}{c|ccc}
\hline & ORM & FRF(100)/FRF(200) & Average \\
\hline A & 0.55 & 7.92 & 199 \\
B & 0.52 & 11.03 & 106 \\
C & 0.60 & 9.28 & 141 \\
D & 0.60 & 9.26 & 160 \\
\hline
\end{tabular}

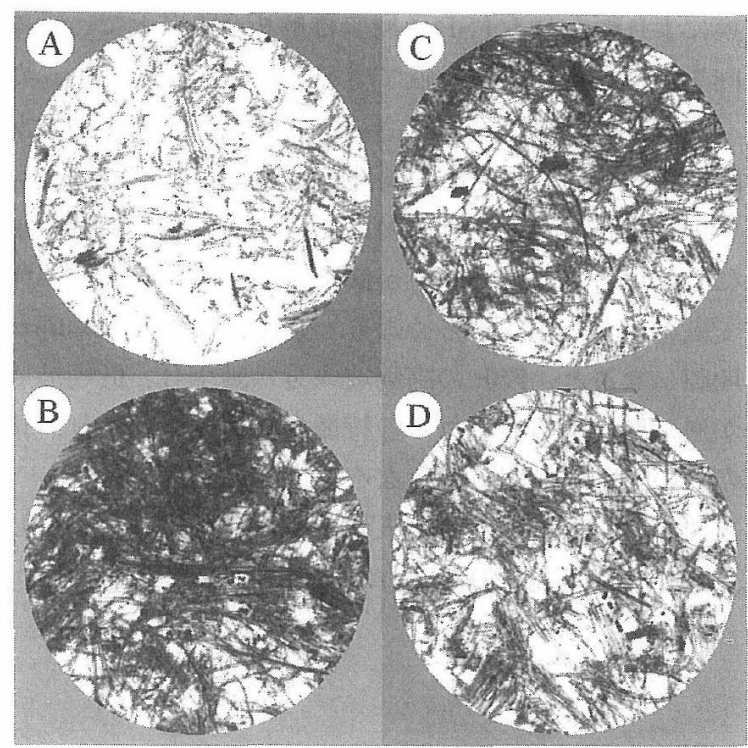

Fig. 6. Sample images of a relatively thin section (A), of a too thick section (B) and proper sections (C and D).

PSP からドーナツ状の周波数帯 (半径 \pm 5 画素) のパ ワースペクトルを取り出し, 全パワースペクトルの合計 で割った值を FRF (frequency rate function) とする。 Fig. 6 の画像から解析した結果, 半径 100 画素のものと 半径 200 画素のものの比を FRF（100）/FRF（200）と し, Table IIに示す。平均輝度の高い場合, つまり画像 中に存在する䋊維数の少ない場合 (Fig. 6-A) にはFRF (100) /FRF（200）值が小さく, 平均輝度が低い場合, つまり繊維が多すぎる場合（Fig，6-B）には值が大きい。 Fig. 6-C，Dに見られる状態が理想的であるうと思われ， これらの值を利用すると，適切な試片の厚さや䋐維量の 評価を行うことが可能であらう。今回の試片では，適切 な試験片の厚さの検討を考慮には入れていなかったので 十分な評価はできないが，今後試験体厚さとPSP の関係 や，コンピュータシミュレーションを使った理想的な繊 維量の検討を行っていく必要がある。また, PSPの極座 標解析で配向性の抽出に重点を置き, 配向性を反映しや すい高周波領域を取り込多, 愦差至招きやすい低周波領 域を取り込まないという方針で, 経験的に具体的な㓮波 数の数值を決定した。しかし，周波数成分には纎維の大 きさやアスペクト比等の情報が含まれており，周波数成 分についての解析を詳しく行うことで，配向性だけでは なく棈成要素の形態特性を評価することも可能となる。 この点についてもさらなる研究定必要とする。

$$
4 \text { ま と }
$$

繊維板の内部の繊維配向を評洒するのは従来難しいと されていたが，縰維板を硬いエポキシ樹脂で包埋し，さ らに者沸によってもろくすることで繊維の配向状態を維 持したまま内部を切り出すことが可能となり，IBの繊維 配向の 3 次元的評価に成功した。また，2次元フーリエ 
変換により得られるPSP を極座標解析することで, 繊維 配向をある程度正確に評価できることが確認できた，た だ，配向性の評価は切片厚さに影響され，ここの繊維が 明嘹に画像化されるための条件設定には, PSP の周波数 分布の解析が有効と考えられる。すなわち切片が薄い場 合には全体としてのパワーが低下する．また切片が厚す ぎて繊維相互の重複が多くなり, 個々の䋊維像の輪郭が 不明瞭になると, PSPの高周波成分が減少し, 低周波成 分が逆に増加する.これらの特徵を利用すればより信頼 性の高い配向評価が可能となろう.

本研究の一部は，著者が大建工業(株在職中に行いまし た。同社開発研究所のご協力に, 謹んで謝意を表します。

\section{参 考 文 献}

1）川井秀一, 佐々木 光, 木材学会誌, 36, 218 (1989).

2) T. Yuhara, M. Hasuike and K. Murakami, Journal Pulp and Paper Science, 17, J110 (1991).

3) 板東貴司, 坂本一秀, 岩田 弘, 蓮池牧雄, 紙 枝協誌, 45, 841 (1995).

4 ) B. Xu and Y. Ting, Textile Res. J., 65, 41 (1995).

5) H. Yaguchi, H. Hojo, D. G. Lee and E. G. Kim, Intern. Polymer Processing X, 10, 262 (1995).

6) B. Pourdeyhimi and R. Ramandathan, Polymer \& Polymer Composites, 3, 277 (1995).

7) 藤田 稔, 梶田 熙, 前川知之, 佐伯 浩, 材料, 44, 267 (1995).

8 ）前川知之, 藤田 稔, 佐伯 浩, 材料, 42, 126 (1993). 